\title{
Counseling Native Americans
}

\section{ROBERT K. HEINRICH, JOSEPH L. CORBINE, and KENNETH R. THOMAS}

This article addresses the issues facing White counselors in providing services to Native Americans, whose values differ significantly from the dominant culture's. Native Americans have been consistently threatened with cultural assimilation. Previously published recommendations to counselors are reviewed and the relevance and possible uses of traditional Native American healing practices are discussed. One such practice, the vision quest, is described in detail. Counselors need to learn culturally relevant metaphors in order to promote healing and change and, in effect, must themselves undergo an acculturation process.

$\mathrm{N}$ ative Americans face enormous problems: unemployment rates of $18 \%$ to $66 \%$ compared to rates of $5.8 \%$ to $7.4 \%$ for the U.S. population at large (Office for Governmental Affairs and the Rural Condition, 1985); a median income only $50 \%$ of that for Whites, (U.S. Department of Health and Human Services, 1977); high school dropout rates reaching 60\% (Gade, Hurlburt, \& Fuqua, 1986); an increase in adolescent suicides of $1,000 \%$ over the past 20 years (Berlin, 1984); arrest rates 10 times those for Whites and 3 times those for Blacks (Blanks, 1982); high rates of drug use (Beauvais, 1980); and an alcoholism rate that is double the national average (Bock et al., 1972).

The general inability of counseling to respond to these problems has also been evident. Sue (1977) found that $55 \%$ of Native American clients did not return after an initial visit to 1 of 17 community mental health clinics in Seattle. In a review of both subjective and empirical studies concerning counseling and psychotherapy with Native Americans, Darou (1987) stated, "this is unsettling research. Non-native counselors have difficulty helping even highly motivated clients" (p. 37). Other authors have also spoken pessimistically of conventional counseling practices in working with Native Americans (Carlson, 1975; Hanson, 1980; Katz, 1981; Lowrey, 1983; Metcalf, 1979; Trimble, 1981).

Given their overwhelmingly bitter experience with Whites historically, it is not unexpected that many Native Americans view Whites with suspicion and even hostility (Archuleta, 1972; Richardson, 1981). A psychiatrist who has worked with Native Americans for 20 years stated, "If you're going to survive in Indian country, you have to learn how to deal with anger" (Hammerschlag, 1988, p. 21). Katz (1981) emphasized the importance of opening up the issue of Native American-White relationships early on in therapy with an eye toward moving beyond stereotypes to individuals. Counselors must be able to depersonalize clients' anger towards Whites (Carlson, 1975).

Richardson (1981) observed that the dominant culture is obsessive-compulsive, arrogant, has a fetish for an all-or-nothing approach to life, and discounts its own inadequacies, which it partly suppresses and partly projects as an inadequacy of other people. This latter characteristic, especially, is reminiscent of Searles's (1967) description of the "dedicated physician," who represses the ingredients of his own diabolized self-image-his hatred, "rejectingness," and lack of feeling - and projects these traits onto the patient. By so doing, the physician (counselor) is protected from his or her own inadequacies and keeps the patient (client) isolated and downtrodden. Ironically, it is the helper's recognition of these "countertransference" reactions that offers the best opportunity for positive growth-in both the helpee and the helper.

Various authors have made both technical and general suggestions for counselors working with Native American clients. Therapists may need to change their usual 50-minute hour, move the counseling environment out of the office, permit drop-ins, and pay particular attention to nonverbal communication (Katz, 1981). Native Americans in counseling may demonstrate silence, apparent nonattentiveness, passive noncompliance, and conformity (Trimble, 1981). Counselors will need patience, understanding, and acceptance (Carlson, 1975). Native Americans often resent the situational demand of self-disclosure and perceive the counselor's questions as intrusive and inappropriate. Flexibility and openness to learning are suggested (Darou, 1987). Bryde (1971) encouraged counselors to show sincere respect and interest, use silence as a positive act, describe options and suggest solutions, and speak softly. Richardson (1981) asked that counselors admit their ignorance, be eclectic and adaptable, and concentrate on problems, not personalities. He suggested techniques of silence, restatement, and general leads as best for counselors beginning work with Native Americans. In describing work done with Native American children, Lazarus (1982) recommended nonverbal interaction such as play and art, becoming comfortable with long pauses in conversations, using the Native American extended family as a resource, and facilitating group work rather than individual work.

Unfortunately, there is little empirical evidence that supports any specific modality for mental health counseling with Native Americans (Manson, 1986). Both nondirective and highly directive approaches have had their supporters (Ford, 1983; Hanson, 1980; Richardson, 1981). The use of an existential framework that does not depend on a set of techniques but on a direct, honest dialogue focused on central, human themes has also been advocated (Hanson \& Eisenbise, 1982). A definition of cross-cultural competency as "the ability of the practitioner to recognize the unique variations of common human themes as they are played out within specific cultures and at specific sociohistorical points" lends support to this view (Valle, 1986, p. 42).

The purpose of this article is two-fold: (1) to provide a review of Native American history, values, and acculturation patterns and (2) to illustrate the possible uses of traditional Native American healing practices and culturally relevant metaphors in counseling.

\section{NATIVE AMERICAN CULTURE}

\section{Values}

There are 478 tribes recognized by the U.S. Bureau of Indian Affairs, plus another 52 tribes without official status. One hundred and forty-nine languages are still being spoken among Native Americans (Manson, 1986). Hanson and Eisenbise (1981) 
gave an overview of some of the historical and cultural differences among these groups. While keeping in mind this enormous diversity among Native Americans, it is possible to identify similarities in values that exist across tribes and regions (Blanchard \& Mackey, 1971; Lazarus, 1982; National Indian Child Abuse and Neglect Resource Center, 1980; Richardson, 1981; Trimble, 1981). Some major value differences between White mainstream culture and traditional Native American culture are presented in Table 1. The contents of this table were derived from a list of 37 such value differences provided by Richardson (1981, pp. 225-227).

The values of traditional Native American culture arose primarily (but not exclusively) within the context of a nomadic, hunting and gathering type of economy that has now been almost completely destroyed. Ford (1983) recounted five stages of U.S. government policy toward Native Americans: (1) removal (17th century to 1840 s) - the period characterized by the saying "the only good Indian is a dead Indian"; (2) reservation (1860 to 1920s) — characterized by the saying "kill the Indian, but save the person"; (3) reorganization (1930s to 1950s)—schools allowed on reservation, easing of cultural repression; (4) termination (1950s to 1960s) - attempts at sociocultural integration, end of dependence on federal government, leading to the sale of large tracts of Native American lands and increased poverty; and (5) self-determination (1973 to the present) — increased tribal sovereignty due in large part to the militant struggles of many Native Americans in the early 1970s.

Historically, White institutions such as government bureaucracies, schools, and churches deliberately have attempted to destroy Native American cultural institutions (Lame Deer \& Erdoes, 1972; Metcalf, 1979). The attitude of many Whites, even today, is characterized by this excerpt from a Wyoming newspaper of the 1870s: "The destiny of the aborigines is written in characters not to be mistaken. The same inscrutable Arbiter that decreed the downfall of Rome has pronounced the doom of extinction upon the red men of America" (Brown, 1970, p. 184). An anonymous Native American eloquently stated, "They made us many promises, more than I can remember, but they never kept but one; they promised to take our land, and they took it" (Brown, 1970, p. 222).

The innovations and successes of Native American culture consistently have been denigrated and denied (Vogel, 1987). Brown (1964) commented:

A further barrier to our understanding is our deep rooted prejudice against the nomadic way of life which many of the
Indian groups followed. We are so blinded by the perspectives of our own society that we can not realize that complex material achievements of the type which we possess, or rather by which we are often possessed, are usually had at the expense of human and spiritual values. ... The nomadic type of culture offers valuable lessons to the contemporary industrial man who is in danger of being crushed by the sheer weight of his civilization, and who therefore often sacrifices the deepest and most meaningful values of life by identifying himself with an endless series of distracting and often destructive gadgets. (pp. 8-9)

It is partly because of the identification of technological progress with human progress that the positive value of Native American culture has been historically minimized.

\section{Acculturation}

Fifty percent of the total Native American population live offreservation (U.S. Bureau of the Census, 1981). Many leave in search of work. This transition is a difficult one, especially for young people moving to high-density urban areas from the reservation. Feelings of loneliness, insecurity, and alienation are common (Carlson, 1975). The dominant culture exerts significant pressure on people to adopt its values. This has been particularly true for the many persons of at least partial Native American genetic heritage who have been raised in White, middle-class environments. Many Native Americans are being shaped to become more "White." Consequently, their degree of interest in traditional Native American culture varies considerably.

Many Native Americans who live in the city dream of making enough money to be able to move back to the reservation at retirement. They may make long commutes to the reservation for feasts, powwows, religious ceremonies, and visits with relatives. Many fear that the traditions will be lost because of the exodus of so many to the city (Mulhern, 1988).

Counselors must be wary of making assumptions about the cultural orientation of Native American clients. The goals of the counseling will depend largely on the tribal heritage of the client and on the counselor's assessment of the client's degree of acculturation. The continuum of acculturation can be generally described as (a) traditional, (b) bicultural, or (c) assimilated (Valle, 1986). Some investigators have developed their own questionnaires to assess acculturation of Native Americans (Hoffman, Dana, \& Bottom, 1985; Kelly, 1967). Zitzow and Estes (1981) developed an 18-item checklist to determine "heritage consistency," which assesses the degree to which a person's customary life-style and activities reflect fundamental themes or aspects of his or her historical tribal culture. Counselors must be sensitive

TABLE 1

Comparison of Value Orientations

\begin{tabular}{ll}
\hline \hline Contemporary Anglo-American Values & Traditional Native American Values \\
\hline $\begin{array}{l}\text { Subjugation of nature } \\
\text { Future, progress, change }\end{array}$ & $\begin{array}{l}\text { Harmony with nature } \\
\text { Competition (each person maximizing own welfare will maximize the }\end{array}$ \\
$\begin{array}{l}\text { general welfare) } \\
\text { Private property, acquisition of wealth }\end{array}$ & $\begin{array}{l}\text { Cooperation, conscious submission of self to the welfare of the tribe } \\
\text { Fame, recognition }\end{array}$ \\
$\begin{array}{l}\text { Reliance on experts } \\
\text { Verbal expression }\end{array}$ & $\begin{array}{l}\text { Anonymity, humility } \\
\text { Analytic }\end{array}$ \\
\hline
\end{tabular}

Note. The data used in this table are from Counseling the culturally different (pp. 225-227) by D. W. Sue (Ed.), 1981, New York: John Wiley \& Sons. (C) Copyright 1981. Reprinted by permission of John Wiley \& Sons. 
to issues facing both heritage-inconsistent clients as well as heritage-consistent clients.

The "dual perspective" is described by Hanson and Eisenbise (1981) as a cognitive and attitudinal assessment approach that depends on the idea that "every individual is part of two systems: the larger system of the dominant society, and the smaller system of the client's immediate physical and social environment" (p. 94). It consists of "the conscious and systematic process of perceiving, understanding, and comparing simultaneously the values, attitudes, and behavior of the larger societal system with those of the client's immediate family and community system" (p. 94). This approach is useful in that it acknowledges the reality and validity of minority cultures and gives the counselor a frame of reference from which to work.

The long-standing idea of cultural assimilation as an end solution to the Native American problem is untenable and may be viewed as genocide by minority persons (Ford, 1983). A Navaho man stated, "In general, Indian people do not wish to be assimilated into the 'dominant culture' and to recognize this is important” (Rehab Brief, 1986). A Chippewa Indian elaborated:

We view this place (North America) as being given to us by the Creator to take care of and to pass onto our future generations. We believe all other people are visitors, and when they leave, we'll still be here to pick up the pieces, no matter what shape it's in. (Mulhern, 1988, p. 1)

\section{Native American View of Health}

The key concept of Native American philosophy is holism, and one of the most important symbols is the circle, or hoop of life. The famous Sioux medicine man Black Elk remarked:

You have noticed that everything an Indian does is in a circle, and that is because the Power of the World always works in circles, and everything tries to be round. In the old days when we were a strong and happy people, all our power came to us from the sacred hoop of the nation, and so long as the hoop was unbroken, the people flourished. (Brown, 1964, pp. 13-14)

Mind, body, spirit, and nature are perceived as one process and little separation exists between religion, medicine, and the activities of daily life (Kaplan \&Johnson, 1964; Richardson, 1981). Reverence for nature and for life is central. The Native American perceives some of the qualities of the Creator reflected in all forms of nature, so that these forms are actual links between human beings and the Deity (Brown, 1964). Illness is identified as a disruption of the essential harmony of life, or as an imbalance of various elements, or as a break in the hoop of life.

To be effective, therapists and counselors must be able to identify these crucial aspects of their minority client's culture: (a) ways in which health and illness are explained; (b) specific categories of illness and dysfunction; and (c) the meanings attributed to various symptoms and feelings (Good \& Good, 1986). Every culture produces characteristic tensions and its own characteristic way of working through those tensions. Although there are fundamental similarities between psychotherapies throughout the world (e.g., confession, suggestion, reassurance, and direct influence), the specific forms of therapy are highly culture bound. For example, Carl Rogers observed that probably lurking in the background of his theory is the individualism of the American frontier, the belief in self-reliance, and the conviction that individuals could learn and do what was necessary for them to learn and do (Meador \& Rogers, 1984). It is therefore imperative that clinicians understand the cultural and personal meanings and values that are invested in their own counseling paradigms and rituals (Good \& Good,
1986; Stubbins, 1978). The traditional healing practices of minority cultures have both relevance and validity for the counselor working with persons from those cultures. One such example worthy of more discussion is the vision quest.

\section{THE VISION QUEST}

Historically, the vision quest was both a rite of passage for young boys and a rite of religious renewal for adult men (Brown, 1964; Tooker, 1979). "The vision quest, like psychotherapy, is a transforming ritual" (Hammerschlag, 1988, p. 53). Recently this traditional ritual has been used in helping contemporary people negotiate difficult life transitions (Foster \& Little, 1987). The following narrative, which describes the sweat lodge and vision quest in some detail, is drawn from sources representing several tribes: Menominee, Winnebago, Sioux, Crow, Cheyenne, and Eskimo (Halifax, 1979; Lame Deer \& Erdoes, 1972; Neihardt, 1932; Spindler \& Spindler, 1971; Tooker, 1979).

A young Native American lad of perhaps 14 or 15 is led into a small wigwam or sweat lodge. Here he will embark on the most significant episode of his young life, an episode that will have a far-reaching impact on the whole of his remaining existence. For in this 6-by-6-foot airtight cubicle made of saplings, birch bark, and hides he will prepare himself for the vision quest that will immediately follow. The ceremony that follows is designed to purify both the body and the spirit for this event.

He enters the door that is facing the East just as the sun enters the world each day. The solemnity and sacredness of the moment is attested to by the bed of cedar and sage upon which he sits and which covers the entrance and interior floor except for a pit dug in its center. Into this pit are placed the red hot rocks that have been heating in the fire outside and upon which is sprinkled the medicinal herbal water producing the intense steam symbolizing his people's ascending prayers to the Great Spirit in the heavens above.

The sweat is created by four separate inclusions of hot stones, representing the four ordinal points of the universe. The stones are added over a period of time to allow for the prayers to the deities of each of these points to continue for hours. The medicine man inside the lodge with the young man will assist him in his prayers. The intent of these sublimations is to provide spiritual guidance and to place the young man's body and mind in the proper receptive state for the real test, which is yet to come.

Upon emerging from the sweat lodge, the young man makes another prayer and offering of tobacco to the four directions, again asking help in his endeavor. He is now ready for that all-important experience-his vision quest-his search for a sign or signs that will lead him on the path he is to follow for the rest of his life.

Next the youth is taken to a remote and isolated area set aside for just this purpose. He will be left totally alone and will have no contact with another human being for the 4 days and nights he will spend at this site (although family members will probably check on his well-being from time to time without his knowledge). He might be placed on a platform above the ground for some security, but he will bring nothing with him. There he will sit, without food and water, for 4 days and nights. His time will be spent in reflection and prayer. He will ponder what his family and tribal elders have told him. He will remember the teachings and his experiences. He will examine his goals and plans. He will think about his future. He will search for a vision.

His fasting will allow his mental capacities to be more attentive to the natural world around him, to be directed toward and singularly focused on his relationship with the universe and the 
role he is to play in it. He will marshal all his abilities, skills, fears, experiences, goals, and hopes to further the quest. Whether it be in a dream state or in full consciousness, something, some one thing or series of events, will reveal to this young Native American man a strikingly real element of the future he must follow. He will have sought after and received some vision of his role, his life's work.

And so it was in the traditional Native American way of life that something so profound took place during this vision experience that it was to be the deciding factor of whether a young man would become a great warrior, hunter, medicine man, or even a chief. A detailed exposition of the symbolic elements of the sweat lodge ceremony will be helpful in understanding metaphors of health in Native American culture.

\section{Meaning of the Sweat Lodge Symbols}

The circular shape of the sweat lodge represents the Universe itself, and the pit at the lodge's center is the navel of the Universe wherein dwells the Great Spirit, with the fire representing the power of God. The willow branches that form the frame of the lodge represent all growing things, whose annual cycles of defoliation and refoliation symbolize death and rebirth in the spirit. The rocks represent the earth and also the indestructible nature of the Creator. The water sprinkled on the rocks is the ever-flowing, life-giving Spirit of God and the steam is both the holy breath of the Universe and the visible prayers of the people. The opening of the flap of the sweat lodge to let in cooling air and light symbolizes liberation from the darkness of ignorance and ego and entering the world of light and truth and goodness (Brown, 1964; Halifax, 1979). 'What is—for the 20th century, Anglicized human being - mere inanimate matter or at best an inferior form of life, is for the Native American fully alive and charged with power, spirit, and meaning. The sweat lodge ceremony is an integral part of the vision quest. In turn, the vision quest is a culturally specific form of a general class of human experience called "rites of passage," a concept that can be useful to counselors.

"A rite of passage is the traditional cultural answer to a personal crisis of meaning" (Foster \& Little, 1987, p. 32). The three phases common to all transitions have been described as (1) severanceseparation from the context of everyday life and everyday meanings; (2) threshold - direct experience of transition, entering the unknown and receiving new knowledge and power; and (3) reincorporation - return to the everyday world, with community support in living out externally the internal changes that have happened (Van Gennep, 1960). The process of death, transformation, and rebirth may be the most basic metaphor of life and can clearly be seen in many mythologies and religious stories (Campbell, 1949). A single, individual life may be seen as being composed of many deaths and rebirths, but often of such small magnitude that they go unnoticed.

\section{THE VISION QUEST AND TRADITIONAL HEALING PRACTICES IN COUNSELING}

The vision quest could be creatively incorporated into individual treatment strategies or implemented within ongoing treatment programs. Outward Bound Schools (and wilderness education programs modeled on them) have used the 1- to 3-day wilderness solo experience in helping troubled adolescents and correctional facilities inmates to reduce depression, tension, and rage and to develop a more positive self-concept (Colorado Outward Bound School, 1969; Kimball, 1979; Marsh, Richards, \& Barnes, 1986).
The solo experience resembles the vision quest stripped of its cultural context of spiritual symbols and meanings.

The threefold process of severance, threshold, and reincorporation provides a frame of reference for the vision quest. It also describes the essential course of dynamic psychotherapy which, according to Whitaker and Malone (1953), involves for the therapist and client: (a) "isolation from the physical, social, and cultural worlds which surround their relationship" (p. 88), leading to an experience in which (b) "the therapist tips the scales by denying all reality, including even the realities of the interview situation and of words and behavior. . [which] thus precipitates the patient [client] into an acultural, deeply affective therapeutic psychosis which is usually nonverbal" (p. 98) and finally (c) "after the interviews are completed, the patient [client] still has the problem of integrating the gains of therapy into his [her] real life function within the culture" (p. 84).

If the counseling process is concerned with finding one's way and with the recovery of purpose and meaning, then the vision quest is an important, culturally relevant metaphor for counselors. In speaking of this rite, Brown (1964) wrote:

This sacred retreat is still practiced by a number of Plains Indian men and women who have the wisdom to know that without vision man loses his sense of relationship and harmony with the world around him; he is caught up in the darkness of his ego, and too easily forgets the purpose for which he was given the precious gift of life. (p. 21)

Manson (1986) reported that "many traditional Indian and Native healing practices are gradually being incorporated into contemporary approaches to mental health treatment" (p. 64). He described three such practices as (1) four circles - concentric circles of relationship between client and Creator, spouse, nuclear family, and extended family as a culturally based structural concept for self-understanding; (2) talking circle-a forum for expressing thoughts and feelings in an environment of total acceptance without time constraints, using sacred objects (e.g., feathers or stones), the pipe, and prayer; and (3) sweat lodge-a physical and spiritual self-purification ritual emphasizing the relationship of the human being to all of creation. Hall (1986) reported that the sweat lodge ceremony was being used or encouraged in 22 of 44 Indian Health Service alcohol treatment programs surveyed. She concluded, "The possibility exists that, fostered by but not controlled by or restricted to alcohol treatment programs, the sweat lodge may have a major role in the prevention of alcohol abuse and in the creation of a new Indian identity" (p. 176). In another treatment strategy, the problem of child abuse was addressed by creating surrogate extended-family networks in urban areas (Metcalf, 1979).

The work of healing is most effectively done with metaphors: "Traditional healing systems draw on metaphors resonant within the culture to construct the illness reality and then symbolically manipulate it to effect healing" (Good \& Good, 1986, p. 18). Counselors must be able to identify what these metaphors are within the client's reality. "Now, if a patient believes in rituals and sacraments, I put down cedar. I use feathers and herbs. It isn't that I have any magic; it's the rituals and their sacramental quality - they are healing" (Hammerschlag, 1988, p. 87). Familiarity with traditional healing practices can provide access to those metaphors.

\section{CONCLUSIONS}

Although Native Americans are a small minority of the U.S. population, they are burdened with a disproportionate share of 
social and economic problems. They are often caught between two cultures; their own historical tribal culture has been oppressed, often violently, by a dominant culture that has consistently devalued and ignored the achievements of the tribal culture, glorifying instead the ideal of cultural assimilation (the so-called melting pot). And yet, because of the confiscation of their lands, Native Americans must in some way depend on the dominant culture for the provision of basic life necessities while often feeling in conflict with the values and models of success of that culture.

Stubbins (1978) remarked that although counseling practices are generally acknowledged as biased, there is little admission that acceptance of counseling services implies some degree of cultural compromise on the part of the minority client. In order to be effective, however, counselors may have to make a cultural shift or adjustment toward the client's cultural background. Mere tolerance of minority cultural values is not enough. Richardson (1981) recommended that counselors seek out exposure to Native American culture through activities such as (a) visiting reservations and cultural centers; (b) speaking with Native American people; (c) attending rodeos, powwows, and dances; and (d) taking courses and becoming familiar with Native American heroes, heroines, and famous contemporary Native Americans.

Arguments have been made for the superiority of Native American counselors to White counselors in working with Native Americans (Darou, 1987; Haviland, Horswill, O'Connell, \& Dynneson, 1983; Luftig, 1983). Trustworthiness, however, has been identified as a more significant variable in counselor effectiveness than ethnicity (Lafromboise \& Dixon, 1981; Lazarus, 1982).

The institution of counseling performs a therapeutic function in the culture from which it originates. According to Whitaker and Malone (1953), clients

who leave psychotherapy must enter a community of cultural values and function adequately in a real sense. Therefore, psychotherapy must be based on some of the given values around which the culture is patterned. There must be some unity of purpose between psychotherapy and the culture. (p. 43)

If this is true, then the counselor is presented with a dilemma when working with someone from a culture that holds values in opposition to those of the counselor's culture of origin.

The counselor can make adjustments in the technical aspects of the craft of counseling, but is this sufficient? Counselors must affirm that minority cultures are not inherently inferior and that they possess values and meanings that are, at least in some dimensions, superior to those of the dominant culture. In addition, counselors must be invested in learning, intellectually and affectively, a new language of culturally relevant metaphors that will, at least temporarily, alter their perceptions of what is real and what is possible. Culture has as its purpose the gratification of deep human needs. The presence of these deep needs expresses an answer to the question, "What do we know that is really true about human life?" It is always toward truth, however symbolized, that the counselor must aim.

\section{REFERENCES}

Archuleta, C. (1972). To help my people: The evolution of a paraprofessional. Durango, CO: Psychosocial Enterprises, Inc. (ERIC Document Reproduction Service No. ED 220 218)

Beauvais, F. (1980). Preventing drug abuse among American Indian young people. Ft. Collins. CO: Colorado State University. (ERIC Document Reproduction Service No. ED 196 630)

Berlin, I. N. (1984). Suicide among American Indian adolescents. National
American Indian Court Judges Association. (ERIC Document Reproduction Service No. ED 245 847)

Blanchard, E., \& Mackey, J. (1971). The American Indian. (SRS Training Grant 755 T 70). Washington, DC: National Rehabilitation Association.

Blanks, R. S. (1982). The inequality of justice: A report on crime and the administration of justice in the minority community. Washington, DC: National Minority Advisory Council on Criminal Justice. (ERIC Document Reproduction Service No. ED 218 384)

Bock, G., Fortuine, R., Bergman, R., Bopp, J., Exendine, J., Lafromboise, R., Maynard, E., Miller, S., Prins, B., \& Rhodes, S. (1972). Alcoholism-A high priority health problem. Rockville, MD: Indian Health Service Task Force on Alcoholism. (ERIC Document Reproduction Service No. ED 148 536)

Brown, D. (1970). Bury my heart at Wounded Knee. New York: Holt, Rinehart \& Winston.

Brown, J. E. (1964). The spiritual legacy of the American Indian. (Pamphlet No. 135). Wallingford, PA: Pendle Hill Publications.

Bryde, J. F. (1971). Indian students and guidance. Boston: Houghton Mifflin. Campbell, J. (1949). Hero with a thousand faces. New York: Bollingen.

Carlson, E. (1975). Counselling in native context. Canada's Mental Health, 23, 7-9.

Colorado Outward Bound School. (1969). Urban bound: A report to the Boettcher Foundation and to the Donner Foundation. Denver, CO: Author. (ERIC Document Reproduction Service No. ED 198 997)

Darou, W. G. (1987). Counselling and the northern native. Canadian Journal of Counselling, 21, 33-41.

Ford, R. (1983). Counseling strategies for ethnic minority students. Tacoma, WA: University of Puget Sound. (ERIC Document Reproduction Service No. ED 247 504)

Foster, S., \& Little, M. (1987). The book of the vision quest: Personal transformation in the wilderness. New York: Prentice Hall.

Gade, E., Hurlburt, G., \& Fuqua, D. (1986). Study habits and attitudes of American Indian students: Implications for counselors. School Counselor, 34, 135-139.

Good, B. J., \& Good, M. J. D. V. (1986). The cultural context of diagnosis and therapy: A view from medical anthropology. In M. R. Miranda \& H. H. L. Kitano (Eds.). Mental health research and practice in minority communities: Development of culturally sensitive training programs ( $\mathrm{pp}$. 1-27). Rockville, MD: National Institute of Mental Health. (ERIC Document Reproduction Service No. ED 278 754)

Halifax, J. (1979). Shamanic voices: A survey of visionary narratives. New York: Dutton.

Hall, R. L. (1986). Alcohol treatment in American Indian populations: An indigenous treatment modality compared with traditional approaches. In T. F. Babor (Ed.), Alcohol and culture: Comparative perspectives from Europe and America. New York: New York Academy of Sciences.

Hammerschlag, C. A. (1988). The dancing healers. San Francisco: Harper \& Row.

Hanson, W. D. (1980). The urban Indian. San Francisco: San Francisco State University. (ERIC Document Reproduction Service No. ED 231 587)

Hanson, W. D., \& Eisenbise, M. D. (1981). Human behavior and American Indians. San Francisco: San Francisco State University. (ERIC Document Reproduction Service No. ED 231 589)

Hanson, W. D., \& Eisenbise, M. D. (1982). Social work methods of intervention with American Indians. San Francisco: San Francisco State University. (ERIC Document Reproduction Service No. ED 231 590)

Haviland, M., Horswill, R., O’Connell, J., \& Dynneson, V. (1983). Native American college students' preference for counselor race and sex and the likelihood of their use of a counseling center. Journal of Counseling Psychology, 30, 267-270.

Hoffman, T., Dana, R. H., \& Bottom, B. (1985). Measured acculturation and MMPI-168 performance of Native American adults. Journal of Cross-Cultural Psychology, 16, 243-256.

Kaplan, B., \& Johnson, D. (1964). The social meaning of Navaho psychopathology and psychotherapy. In A. Kiev (Ed.), Magic, faith, and healing (pp. 203-229). New York: MacMillan.

Katz, P. (1981). Psychotherapy with Native adolescents. Canadian Journal of Psychiatry, 26, 455-459.

Kelly, R. E. (1967). Disabled Navaho Indians and rehabilitation: An anthropological overview. (Navaho Rehabilitation Project Technical Report No. 2). Flagstaff, AZ: Northern Arizona University. (Research \& Demonstration Grant No. RD-1213-G).

Kimball, R. O. (1979). Wilderness experience program: Final evaluation report. New Mexico: Health and Environment Dept. (ERIC Document Reproduction Service No. ED 179 327)

Lafromboise, T. D., \& Dixon, D. N. (1981). American Indian perception of trustworthiness in a counseling interview. Journal of Counseling Psychology, 28, 165-169. 
Lame Deer, J., \& Erdoes, R. (1972). Lame Deer: Seeker of visions. New York: Simon\&Schuster.

Lazarus, P. (1982). Counseling the Native American child: A question of values. Elementary School Guidance and Counseling, 17, 83-88.

Lowrey, L. (1983). Bridging a culture in counseling. Journal of Applied Rehabilitation Counseling, 14, 69-73.

Luftig, R. L. (1983). Effects of schooling on the self-concept of Native American students. School Counselor, 30, 251-260.

Manson, S. M. (1986). Recent advances in American Indian mental health research: Implications for clinical research and training. In M. R. Miranda \& H. H. L. Kitano (Eds.). Mental health research and practice in minority communities: Development of culturally sensitive training programs (pp. 51-89). Rockville, MD): National Institute of Mental Health. (ERIC Document Reproduction Service No. ED 278 754)

Marsh, H. W., Richards, G. E., \& Barnes, J. (1986). Multidimensional self-concepts: The effect of participation in an Outward Bound program. Journal of Personality and Social Psychology, 50, 195-204.

Meador, B. D., \& Rogers, C. R. (1984). Person-centered therapy. In R. J. Corsini (Ed.), Current psychotherapies (3rd ed., pp. 142-195). Itasca, IL: Peacock.

Metcalf, A. (1979). Family reunion: Networks and treatment in a Native American community. Group Psychotherapy, Psychodrama \& Sociometry, 32, 179-189.

Mulhern, B. (1988, September 26-October 1). Wisconsin's Indians: Their progress, their plight. The Capital Times, p. 1.

National Indian Child Abuse and Neglect Resource Center. (1980). The social worker and the Indian client. Tulsa, OK: Author.

Neihardt, J. G. (1932). Black Elk speaks. New York: Simon \& Schuster.

Office for Governmental Affairs and the Rural Condition. (1985). American Indian unemployment-confronting a distressing reality. Washington, DC.: Full Employment Action Council. (ERIC Document Reproduction Service No. ED 275 472)

Rehab Brief. (1986). Cross-cultural rehabilitation: Working with the Native American population, IX(5). Washington, DC: National Institute of Handicapped Research.

Richardson, E. H. (1981). Cultural and historical perspectives in counseling American Indians. In D. W. Sue (Ed.), Counseling the culturally different. New York: Wiley.

Searles, H. (1967). The "dedicated physician" in the field of psychotherapy and psychoanalysis. In R. W. Gibson (Ed.), Cross-currents in psychiatry and psychoanalysis (pp. 128-143). Philadelphia: Lippincott.

Spindler, G., \& Spindler, L. (1971). Dreamers without power: The Menomini Indians. New York: Holt, Rinehart\&Winston.
Stubbins, J. (1978). Cross cultural factors in the rehabilitation of Navahos and Micronesians. In J. L. Steinberg (Ed.), Cultural factors in the rehabilitation process (pp. 1-59). Tsaile, AZ: Rehabilitation Services Administiation.

Sue, S. (1977). Community mental health services to minority groups: Some optimism, some pessimism. American Psychologist, 32, 616-624.

Tooker, E. (1979). Native North American spirituality of the eastern woodlands. New York: Paulist Press.

Trimble, J. E. (1981). Value differentials and their importance in counseling American Indians. In P. Petersen, J. Draguns, W. Conner, \& J. Trimble (Eds.), Counseling across cultures (pp. 203-226). Honolulu, HI: University Press of Hawaii.

U.S. Bureau of the Census. (1981). Census of the population: 1980. Washington, DC: U. S. Government Printing Office.

U.S. Department of Health and Human Services. Office of Health Resources Opportunity. (1977). Health of the disadvantaged chart book. Washington, DC: U. S. Government Printing Office.

Valle, R. (1986). Cross-cultural competence in minority communities: A curriculum implementation strategy. In M. R. Miranda \& H. H. L. Kitano (Eds.), Mental health research and practice in minority communities: Development of culturally sensitive training programs (pp. 29-49). Rockville, MD: National Institute of Mental Health. (ERIC Document Reproduction Service No. ED 278 754)

VanGennep, A. (1960). The rites of passage. Chicago: University of Chicago Press.

Vogel, V. J. (1987). The blackout of Native American cultural achievements. American Indian Quarterly, 11, 11-35.

Whitaker, C. A., \& Malone, T. P. (1953). The roots of psychotherapy. New York: The Blakiston Co.

Zitzow, D., \& Estes, G. (1981). Heritage consistence as a consideration in counseling Native Americans. Aberdeen, SD. (ERIC Document Reproduction Service No. ED 209 035)

Robert K. Heinrich is a doctoral student in the Department of Psychology, University of Michigan, Ann Arbor. Joseph L. Corbine is a doctoral student in the Department of Rehabilitation Psychology and Special Education, University of Wisconsin-Madison. He is past chairman of the Bad River Tribe of the Lake Superior Chippewa Indians. Kenneth R. Thomas is a professor, Department of Rehabilitation Psychology and Special Education, University of Wisconsin-Madison. Correspondence regarding this article should be sent to Robert K. Heinrich, Dept. of Psychology, K-406, University of Michigan, 580 Union Drive, Ann Arbor, MI 48109. 